\title{
Microwave and Optical Electric Field Interaction in Microwave Polarization Detector Based on Photonic Technology for EMC Measurement
}

\section{Interaksi Medan Listrik Gelombang Mikro dan Optik pada Pendeteksi Polarisasi Gelombang Mikro Berbasis Teknologi Fotonik untuk Pengukuran EMC}

\author{
Yusuf Nur Wijayanto",a , Hiroshi Murata ${ }^{\text {b }}$ I Dewa Putu Hermida ${ }^{\text {a }}$ \\ ${ }^{a}$ Research Center for Electronics and Telecommunication, \\ Indonesian Institute of Sciences (LIPI) \\ Jl. Sangkuriang 21/54D, Bandung 40135 INDONESIA \\ ${ }^{b}$ Graduate School of Engineering Sciences \\ Osaka University 1-3 Machikaneyama, Osaka, JAPAN
}

\begin{abstract}
We analyze the interaction of microwave and optical electric field in a microwave polarization detector based on photonic technology for Electromagnetic Compatibility (EMC) measurement. The detector consists of two orthogonal optical waveguides and patch antennas embedded with two orthogonal gaps fabricated on an Electro-Optic (EO) crystal. Wireless microwave signals can be received, separated and converted directly to lightwave signals through optical modulation using the proposed detector. This detector operates with no external power supply and with low microwave distortion. Microwave polarization can be identified using the proposed interface. In addition, it enables us to measure the magnitude and phase of the wireless signal simultaneously. The analysis of the device was done and presented at the operation frequency of $26 \mathrm{GHz}$. The proposed interface can be applied for EMC measurement through the radio-over-fiber link.
\end{abstract}

Keywords: Microwave, optical, electric field, microwave polarization, EMC.

\section{Abstrak}

Kami menganalisa interaksi antara medan elektrik mikrowave dan optic pada pendeteksian polarisasi microwave berbasis teknologi fotonik untuk pengukuran Electromagnetic Compatibilty (EMC). Detektor tersebut terdiri dari dua pemandu gelombang optic tersusun secara orthogonal dan antena patch tertanam dengan dua gap yang tersusun secara orthogonal juga difabrikasi pada kristal electro-optic (EO). Sinyal microwave nirkabel dapat diterima, dipisahkan, dan diubah secara langsung ke sinyal gelombang cahaya melalui modulasi optic menggunakan detektor yang diajukan tersebut. Detektor ini beroperasi dengan tidak menggunakan catu daya tambahan dan dengan distorsi microwave yang rendah. Polarisasi microwave dapat diidentifikasi menggunakan alat yang diajukan itu. Sebagai tambahan, alat ini dapat untuk mengukur juga magnitude dan fase dari sinyal microwave nirkabel secara bersamaan. Analisa dari devais ini telah dilakukan dan ditunjukkan pada frekuensi operasi $26 \mathrm{GHz}$. Divais yang diajukan ini dapat diaplikasikan untuk pengukuran EMC melalu radio-over-fiber link.

Kata kunci: microwave, optic, medan listrik, polarisasi microwave, EMC.

\section{INTRODUCTION}

Electromagnetic compatibility (EMC) is the ability of an electronic system to function properly without generating pollution to the electromagnetic environment [1]. EMC test systems for measuring radiation of electromagnetic fields are required to operate with no induction and no interference. Radio-over-Fiber (RoF) technologies can be used for developing EMC test systems with their low transmission loss, no inductance, and passive sensing [2]. In RoF links for EMC test

\footnotetext{
* Corresponding Author.

Email: yusuf.nur.wijayanto@lipi.go.id

Received: October 17, 2016; Revised: -

Accepted: November 28, 2016

Published: December 15, 2016

(c) 2016 PPET - LIPI

doi: 10.14203/jet.v16.7-10
}

systems, an interface to convert wireless electromagnetic field signal to a lightwave signal is important.

The interface can be implemented by combining antennas and electro-optic (EO) modulators using EO optic effects of the ferroelectric optical crystals [3]. An interface using discrete antennas and discrete EO modulator have been developed [3]. However, a connection cable between a discrete antenna and an EO modulator might be caused by a microwave distortion when its frequency becomes higher. Therefore, the interface using integration of antennas and modulation electrodes in the same substrate can be applied for high frequency with low microwave distortion. Several interfaces for converting microwave to lightwave signal using antennas-integrated electrodes were reported with simple and compact structures [4]. However, in the 
integrated interfaces, a $\mathrm{p}$ recise tuning is required to obtain the best performance at the designed microwave wireless signal. An interface using patch antennas embedded with a gap was proposed also [5], [6]. This device can be operated with very low microwave distortion and no precise tuning is required. The basic operations of this device were demonstrated successfully.

In this paper, we design an interface for converting wireless microwave to lightwave signals using two orthogonal optical waveguides and patch antennas embedded with two orthogonal gaps. By using two orthogonal gaps, wireless microwave signals with two orthogonal polarizations can be received, separated, and converted to lightwave signals directly, independently, and simultaneously. Therefore, the polarization information of a wireless microwave signal can be identified using the proposed interface. Therefore, the interface can be used for a sensor to detect wireless microwave polarization by photonic technology in EMC measurement with very low induction.

In the following sections, we will discuss the proposed interface structure and analyze its characteristics. Performance of the proposed interface to detect wireless microwave polarization are also reported and discussed.

\section{Microwave Polarization Detector}

Figure 1 shows the basic structure of an interface for converting wireless microwave to lightwave signals using patch antennas embedded with two orthogonal gaps. It is composed of two orthogonal optical waveguides and a square patch antenna embedded with two orthogonal gaps. It is fabricated on a $Z$-cut ferroelectric optical crystal, since the largest EO effect is considered along $z$-direction. The length of the patch antenna is set at half a wavelength for the designed microwave wireless signal. The gap widths are set in micrometer order to generate strong electric field across the gap. The two orthogonal optical waveguides are located under the edges of the two orthogonal gaps to obtain large interaction between the microwave and optical electric fields. A buffer layer is inserted between the substrate and the patch antenna to minimize optical loss due to metal material. The reverse side of the substrate is covered with a ground electrode.

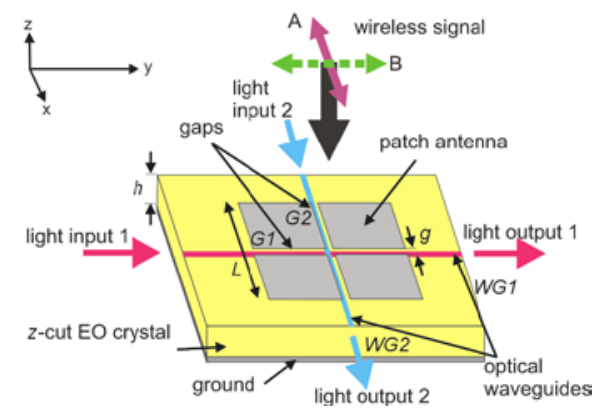

Figure 1. Basic Structure of The Proposed Interface for Converting Microwave to Lightwave Signal.

The basic operational principle of the proposed interface was reported by the such interface using patch antennas embedded with a single gap [5]. When a wireless signal at the designed frequency with two orthogonal linear polarizations, $A$ - and B-polarizations shown in Figure 1, is irradiated to the proposed device, resonant standing-wave microwave currents are appeared on the surface of the patch antenna along $x$ and $y$-axes [7]. By introducing the two orthogonal narrow gaps on the patch antennas, the surface current distributions are kept except for near the gaps and displacement currents are induced across two orthogonal gaps owing to the current flow continuity [8]. Therefore, strong electric fields are also induced across the gaps $G_{1}$ and $G_{2}$ according to the linear polarization components, $A$ - and $B$-polarizations, of the wireless signals. These strong electric fields can be used for optical modulation. When lightwaves propagates into the two orthogonal optical waveguides under the two orthogonal gaps, the lightwaves can be modulated by the wireless signals through an EO effect. As a result, the wireless signals can be received, separated according to the polarization, and converted to the lightwave signals independently and simultaneously. Magnitudes and phases of the two orthogonal polarization components of the wireless microwave signal can be also measured by detecting two modulated lightwaves.

\section{MicrowaVe ANALysis}

The characteristics of the proposed interface in the microwave frequency range were analyzed in detail using electromagnetic field analysis software, High Frequency Structure Simulation (HFSS).

In the standard patch antenna with no gap, when a wireless microwave signal with an arbitrary polarization condition is irradiated to the device, a standing-wave microwave surface current $\mathbf{K}$ is induced on the metal of the patch antenna [6]. It can be expressed as

$$
\mathrm{K}=\hat{x} K_{x}+\hat{y} K_{y},
$$

where, $K_{x}$ and $K_{y}$ are the surface current components along $x$ - and $y$-axes, respectively, and $\hat{x}$ and $\hat{y}$ are the unit vectors along $x$ - and $y$-axes, respectively. $K_{x}$ and $K_{y}$ can be expressed as

$$
\begin{gathered}
K_{x}(x, t)=K_{x p} \cos \left(\omega_{m} t\right) \cos \left(p \frac{2 \pi}{\Lambda_{m}} x\right), \\
K_{y}(y, t)=K_{y q} \cos \left(\omega_{m} t+\varphi\right) \cos \left(q \frac{2 \pi}{\Lambda_{m}} y\right),
\end{gathered}
$$

where, $K_{x p}$ and $K_{y q}$ are the amplitude of the surface current, $\omega_{m}$ is the wireless microwave signal angular frequency, $\Lambda_{m}$ is the microwave wavelength and $\varphi$ is the mutual phase shift between the $x$ - and $y$-current components. For simplicity, we focus on the fundamental mode case, that is $p=1$ and $q=1$. In this mode, the surface current becomes maximum at $x=0$ along the $x$-axis and at $y=0$ along the $y$-axis.

Then, two narrow orthogonal gaps $G_{1}$ and $G_{2}$ are introduced at $x=0$ and $y=0$, respectively as shown in Figure 2(a). The displacement currents must be induced across both the gaps for the current continuity requirement. They can be formulated as 


$$
\begin{array}{r}
G_{1}: \frac{\partial D_{x}}{\partial t} \propto K_{x}(0, t)=K_{x 0} \cos \left(\omega_{m} t\right), \\
G_{2}: \frac{\partial D_{y}}{\partial t} \propto K_{y}(0, t)=K_{y 0} \cos \left(\omega_{m} t+\varphi\right),
\end{array}
$$

where $D$ is the electric flux density $(D=\varepsilon E)$, and $\varepsilon$ is the permittivity. Therefore, the induced electric fields across the gaps are obtained by the time integration of the displacement currents [8]. It can be shown as

$$
\begin{gathered}
E_{x}(t) \propto K_{x 0} \sin \left(\omega_{m} t\right), \\
E_{y}(t) \propto K_{y 0} \sin \left(\omega_{m} t+\varphi\right) .
\end{gathered}
$$

The field distributions on the patch antennas surface were analyzed using HFSS. Figure 2(b), (c), and (d) show the calculated electric field distributions under the patch metal when microwave signals with different polarization conditions are irradiated to the device. When the wireless signal with a linear polarization along $x$-axis is irradiated to the proposed device, the strong electric field is induced across the $G_{1}$ and very weak electric field under the $G_{2}$ as shown in Figure 2(b). On the contrary, when the polarization of the radiated wireless signal is rotated 90-degrees (along $y$-axis), the strong electric field is induced across the $G_{2}$ and very weak electric field under the $G_{1}$ as shown in Figure 2(c). When a wireless signal with a 1 inear polarization with an angle of 45-degrees to $x$ - and $y$ axes is irradiated to the device, the strong electric fields are induced across both orthogonal gaps as shown in Figure 2(d). In this case, the induced electric fields across $G_{1}$ and $G_{2}$ are completely in-phase. When microwave signals with circular polarization states are irradiated to the device, the induced electric fields across $G_{1}$ and $G_{2}$ have the same magnitude with a 90degrees phase difference. By using these characteristics, the polarization condition of the wireless signal can be identified.

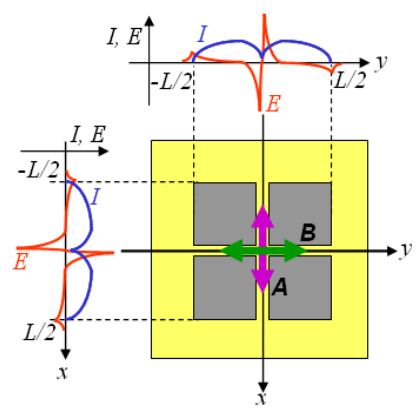

(a)

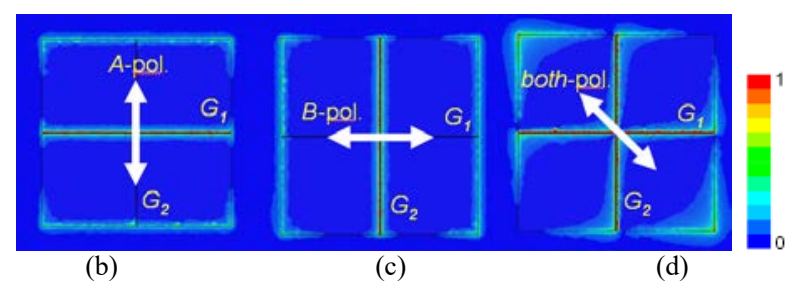

(b)

(c)

(d)

Figure 2. Top View of The Proposed Device and Field Profiles Illustration (a). Simulation results of the field distributions on the patch antenna surface with $A$-polarization (0-degree) (b), $B$ polarization (90-degrees) (c), and both-polarization (45-degrees) (d).

\section{Optical Modulation AnAlysis}

The optical modulation characteristics driven by the electric fields across the gaps were also analyzed. In order to calculate modulation indices through the EO effect, the microwave electric field observed by the lightwave propagating in the optical waveguides should be considered by taking into account the transit-time effect.

The transformation for considering the transit-time effect for the lightwave propagating in the optical waveguide $W G_{1}$ along the $y$-axis, can be expressed by $y^{\prime}=y-v_{g 1} t$, where $y^{\prime}$ denotes the point of the lightwave in the coordinate system moving with the lightwave, and $v_{g}$ is the group velocity of the lightwave. Therefore, the microwave electric fields observed by the lightwave along the $W G_{1}$ become

$$
\begin{aligned}
E_{x}^{o p t}(y) & =E_{x}\left(t=\frac{y-y^{\prime}}{v_{g 1}}\right) \\
& \propto K_{x 0} \sin \left(\omega_{m} \frac{y-y^{\prime}}{v_{g 1}}\right) \\
& =K_{x 0} \sin \left(k_{m} n_{g 1} y+\zeta_{1}\right),
\end{aligned}
$$

where $k_{m}$ is the wave number of the microwave in vacuum $\left(k_{m}=\omega_{m} / c\right), n_{g 1}$ is the group index of the lightwave propagating in the $W G_{1}\left(n_{g 1}=c / v_{g 1}\right), \zeta_{1}$ is an initial phase of the lightwave in the $W G_{1}\left(\zeta_{1}=k_{m} n_{g 1} y^{\prime}\right)$, and $c$ is the light velocity in vacuum.

The lightwave propagating in the $W G_{1}$ is modulated by the induced electric field across the $G_{1}$ through the EO effect. The obtained lightwave from the $W G_{1}$ is phase-modulated light by the wireless microwave signal with $A$-polarization. Its modulation index, $\Delta \phi_{x}$ can be determined taking account of the overlapping between of the induced electric field and the lightwave in the cross section. It is expressed as follows when a transverse magnetic lightwave is used,

$$
\Delta \phi_{x}=\frac{\pi r_{33} n_{e}^{3}}{\lambda_{1}} \Gamma \int_{0}^{L} E_{x}^{o p t}(y) d y,
$$

where $\lambda_{1}$ is the lightwave wavelength propagating in the $W G_{1}, r_{33}$ is the EO coefficient, $n_{e}$ is the extraordinary refractive index of the substrate, $\Gamma$ is a factor expressing the overlapping between the induced microwave electric field and the lightwave, and $L$ is the length of the patch antenna.

The conversion efficiency from the wireless microwave signals to the lightwave signals corresponds to the square of the modulation index of the phasemodulated lightwaves when the modulation index is smaller than 0.1 radian. The phase-modulated lightwaves are easily converted to intensity-modulated lightwave by use of an optical interferometer and a sharp-cut optical filter. The intensity-modulated lightwave can be reconverted to microwave signals using a photodetector for an optical-electrical converter. Therefore, the reconverted microwave signal level is proportional to the square of the modulation index.

Furthermore, the modulation index can be increased using an array of patch antennas as shows in Figure 3(a). The modulation index can be calculated with 
considering an array factor of the patch antennas. The microwave electric field at the $h$-th patch antennas observed by the lightwave propagating in the $W G_{1}$, $E_{x}^{o p t-h}$, can be formulated as

$$
E_{x}^{o p t-h}(y) \propto K_{x 0} \sin \left[k_{m} n_{g 1} y+d_{1}(h-1) k_{m} n_{0} \sin \theta_{1}+\zeta_{1}\right],
$$

where $h$ denotes the number of the antennas, $d_{1}$ is a distance between patch antennas along the $W G_{1}$, and $\theta_{1}$ is the wireless signal irradiation angle in the $y z$-plane. $E_{x}^{o p t-h}(y)$ is illustrated in Figure $3(\mathrm{~b})$. Therefore, the modulation index, $\Delta \phi_{x}$, of the patch antenna array along the $W G_{1}$ can be obtained as

$$
\Delta \phi_{x}(\theta)=\frac{\pi r_{33} n_{e}^{3}}{\lambda_{1}} \Gamma \sum_{h=1}^{N} \int_{(h-1) d_{1}}^{(h-1) d_{1}+L} E_{x}^{o p t-h}(y) d y,
$$

where $N$ is the total number of the patch antennas along the $W G_{1}$

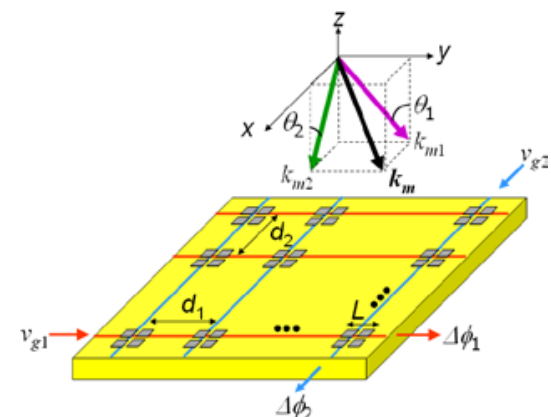

(a)
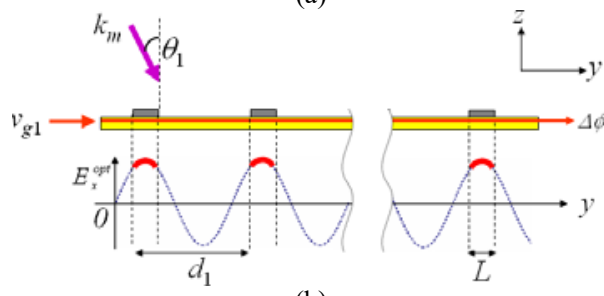

(b)

Figure 3. An $N x M$ array of patch antennas embedded with orthogonal gaps in 3-D view (a). Cross-section view and its microwave electric field observed by lightwave (b).

The optical modulation characteristics in the optical waveguide $W G_{2}$ along $x$-axis can be also calculated using the similar procedure with the optical modulation analysis at the $W G_{1}$. For the array form case, the microwave electric field observed by lightwave, $E_{y}^{o p t-h}$, and the modulation index, $\Delta \phi_{y}$, in the $W G_{2}$ can be expressed as

$$
\begin{gathered}
E_{y}^{o p t-h}(x) \propto K_{y 0} \sin \left[k_{m} n_{g 2} x+d_{2}(h-1) k_{m} n_{0} \sin \theta_{2}+\zeta_{2}+\varphi\right] \\
\Delta \phi_{y}(\theta)=\frac{\pi r_{33} n_{e}^{3}}{\lambda_{2}} \Gamma \sum_{h=1}^{M} \int_{(h-1) d}^{(h-1) d+L} E_{y}^{o p t}(x) d x
\end{gathered}
$$

respectively, where $\lambda_{2}$ is the lightwave wavelength propagating in the $W G_{2}, n_{g 2}$ is the group index of the lightwave in the $W G_{2}\left(n_{g 2}=c / v_{g 2}\right), \zeta_{2}$ is an initial phase of the lightwave in the $W G_{2}\left(\zeta_{2}=k_{m} n_{g 2} x^{\prime}\right), d_{2}$ is a distance between patch antennas along the $W G_{2}, \theta_{2}$ is the wireless signal irradiation angle in the $x z$-plane, and $M$ is the total number of the patch antennas along the $W G_{2}$.
The microwave electric field observed by lightwave in the array form depends on the wireless microwave signal irradiation angle to the device. The irradiation angle for maximum conversion can be controlled by tuning the distances between the patch antennas $d_{1}$ and $d_{2}$. Based on that, a wireless signal at a certain irradiation angle in a three-dimensional (3-D) space can be received and converted directly to lightwave signals by the $N x M$ array of patch antennas embedded with orthogonal gaps.

\section{CONCLUSION}

The interface for detecting wireless microwave polarization using patch antenna embedded with orthogonal gaps was proposed. Interaction of microwave and optical electric fields was also analyzed and discussed. By considering the electric field interaction, the microwave signal can be converted to optical signal using the simple proposed interface as the sensor in EMC measurement. Additionally, the magnitude and phase of the microwave can also be measured using the proposed interface. Therfore, EMC measurement with very low microwave distortion and loss can be obtained especially for high frequency operation.

Now, we are attempting to realize the proposed interface and perform its functionality in EMC measurement.

\section{ACKNOWLEDGMENTS}

This research activity is financially supported in part by Indonesian Institute of Sciences (LIPI) Indonesia through the competitive project of "Development of Optical Environmental Sensors".

\section{REFERENCES}

[1] Henry W. Ott, Electromagnetic Compatibility Engineering, New Jersey : John Wiley \& Sons, Inc., 2009

[2] C. H. Lee, Microwave Photonics, New York : CRC Press Taylor \& Francis Group, 2007.

[3] S. Shinada, T. Kawanishi, and M. Izutsu, "A 10-GHz resonanttype LiNbO3 optical modulator array," IEEE Transaction Electronics, vol. E90-C, no. 5, pp. 1090-1095. 2007.

[4] H. Murata, N. Kohmu, Y. N. Wijayanto, Y. Okamura, "Integration of patch antenna on optical modulators," IEEE Photonics Society News, vol. 28, no. 2, April 2014

[5] Y. N. Wijayanto, H. Murata, and Y. Okamura, "Novel electrooptic microwave-lightwave converters utilizing a patch antenna embedded with a narrow gap," IEICE Electronic Express, vol. 8, no. 7, pp. 491-497. 2011

[6] Y. N. Wijayanto, H. Murata, H. Shiomi, and Y. Okamura "Electro-optic microwave-lightwave converter using patch antenna embedded with a narrow gap for optical modulation," in Proc. of Conference on Lasers and Electro-Optics, Baltimore, USA, May, 2011.

[7] W. Yuyu, S. Ukhty, W. Heroe, T. Yana, S. Arie, "Antena fraktal koch dengan catuan EMC pada UHF untuk aplikasi televisi digital terestrial", Jurnal Elektronika dan Telekomunikasi, vol 15, no 1, pp. 1-5, 2016.

[8] K. Zhang, and D. Li, Electromagnetic Theory for Microwaves and Optoelectronics, Berlin Heidelberg : Springer-Verlag, 2008.

[9] R. Fitzpatrick, Maxwell's Equation and the Principles of Electromagnetism, Hingham : Infinity Science Press, 2008.

[10] R. E. Newnham, Properties of Materials, New York USA: Oxford University Press Inc., 2005. 